\title{
Deliberative Elitism? Distributed Deliberation and the Organization of Epistemic Inequality
}

In this essay I consider the problem of locating expertise in deliberative politics. Given its importance in processes of opinion formation among policy makers and wider publics on issues such as climate change, expert deliberation is a significant topic in its own right. However, I also suggest that the problem of locating expertise within deliberative politics is just a special case of a more general problem in deliberative systems: How to locate different deliberative 'moments' with respect to each other and to observing publics. One aspect of this problem involves the need to take on trust the outcomes of deliberations in other parts of the system, which raises a problem of authority: it involves not making one's acceptance of a command or proposition conditional on an independent examination of the grounds of the command or proposition. This problem arises with respect to public acceptance of the claims issuing from expert deliberation, but it also arises with respect to the outcomes of minipublics that have themselves sometimes been conceived as a response to the problem of bringing public judgment to bear on expertise. ${ }^{1}$ It is in part in response to this problem that some critics have described minipublics as a form of 'deliberative elitism' (Lafont 2014; Urbinati 2010), displacing rather than supplementing public judgment. Far from being a democratic remedy for potentially exclusive and elitist expert deliberation, minipublics are thus thought to themselves represent a form of elitism. In this essay I attempt to locate the problem of 'deliberative elitism' in a broader discussion of the problem of expertise within a democratic system, and the more general question of the grounds on which one might accept the outcomes of a deliberation in which one was not a participant. In answering this question I emphasise the importance of providing conditions that support public judgment at the level of 'metadeliberation' on the value and functions of divisions of deliberative labor itself.

\footnotetext{
${ }^{1}$ It was in the context of his discussion of the difficulties of bringing competent citizen judgment to to bear on delegation to experts in government (seeking delegation without alienation) that Robert Dahl first developed the idea of a 'minipopulus' (Dahl 1985, 76).
} 
I begin the essay with a discussion of the idea of a deliberative system, with particular reference to the problem of expertise. I then consider deliberation among experts, that is, exemplified by expert committees and commissions, where on the one hand participation is exclusive and members are selected for competence, and on the other there is a strong orientation to reason-giving and equality among participants. However, internal means of securing deliberative ideals only go so far. In the third section I describe three ways in which societal practices of contestation and critique contribute to the conditions of possibility of public judgment of expert claims and practices: the articulation of new issues and identities; oversight and scrutiny of expert practices; and the exercise of powers of prevention. In the fourth section, I consider the role of mini publics and citizen panels in relation to the problem of generating the conditions of possibility for public judgments of expertise. And I conclude with a discussion of the danger of 'deliberative elitism'.

\section{The Problem of Expertise in a Deliberative System}

The idea that people ought to have an equal opportunity to contribute to deliberation on matters that affect them seems to be short-circuited by the inequalities in knowledge that are necessary for the effective analysis, regulation and management of complex social and technological problems. This generates serious difficulties for the ideal of government by discussion that is at the heart of deliberative democratic theory. As Dennis Thompson recently noted, democratic theorists have failed to show 'how to incorporate the need for expertise and technical administration in a deliberative democracy' (Thompson, 2008: 515). However, these difficulties become more tractable if we think in terms of a deliberative system. On the systems view deliberation is functionally differentiated or distributed, such that 'different segments or components contribute in different ways to weighing matters that the public ought to discuss, through, e.g., public forums, interest groups, enclaves, everyday talk, and individual contemplation' (Mansbridge 2010: 41). 
Empirical studies of deliberative democratic practice have tended (understandably) to focus on particular sites, modes and moments of deliberation, from established institutions such as parliaments (Steiner et al. 2004) and committees (Nullmeier and Pritzlaff 2010), to recent innovations such as minipublics (Fung 2003), citizens' assemblies (Warren and Pearse 2008) and deliberative polls (Fishkin and Luskin 2005). However, the systems approach, while building on this work, shifts the focus from the 'best possible single deliberative forum' (Mansbridge et al. 2012: 2), to the approximation of deliberative ideals in the interactions between different modes, institutional locations and temporal moments of deliberation.

The deliberative system comprises many sites and venues, including parliaments, expert committees, courtrooms, everyday talk, and civil associations or social movements. These sites can have different deliberative functions and different styles of reasoning and norms of argument. Further, 'each element in such a system may not be perfectly deliberative or democratic in its own right, but may still perform a useful function in the system as a whole' (Parkinson 2006: 7; see also Mansbridge 1999: 224). Indeed, deliberative values may conflict (Thompson 2008: 511), and it is possible that deliberative values at the system level can in fact be better served by departing from deliberative ideals in particular instances. The deliberative value of a particular part of the system depends not only on its internal structure and conduct, but on its context and its relations to other moments.

We can usefully distinguish three ways of thinking about the value of deliberative parts in their relations to one another. The first is aggregation, where one part of the system adds a bit of deliberative value to the aggregate whole. Here the deliberative moments are treated as plug-ins or pieces of a puzzle. The deliberative value of the system is equal to the sum of the deliberative value of its parts. The second is sequencing, where, deliberative moments have value in virtue of being 'in 
the right combinations and the right order' (Goodin 2005: 193). Third is iteration, in which the value of the system depends on opportunities for reopening, revising and contesting particular decisions, settlements and routine decision processes (Thompson 2008: 515). Iterative processes can engage different institutions, harness different deliberative capacities, and go through many phases. In contrast to the formality of an ordered sequence of deliberative moments, the 'iteration' model emphasises the reversibility and revisability of decisions and decision-processes.

While deliberation may be distributed across different moments and institutional locations, the broad regulative ideal remains that "power in the sense of coercive power is absent in a deliberative system' (Mansbridge et al. 2010: 41). Yet the systems view must also, as Ferejohn argues, recognise the 'inevitability of a political division of labour and deference within deliberative processes' (Ferejohn 2008: 203). This gives us a sharper view of a problem that looms large when considering a democratic theory of expertise: How might we have relations of power and deference within a deliberative system and yet imagine that it could approach the regulative ideal of the absence of coercive power? A common response to this question is that divisions of labour and inequalities of influence must themselves be capable of being justified through democratic deliberation. We might say that Thompson's (1999: 185) democratic justification of secrecy, that 'first order secrecy' must be justified through a process based on 'second-order publicity,' extends to many less extreme forms of asymmetry. Minimally, policies and processes must be public in order to be potential objects of consent. A crucial feature of the systems approach, then, is that at the 'meta-deliberative' level, the 'place of deliberation in the larger process should be open to deliberative challenge itself' (Thompson 2008: 515). ${ }^{2}$ Bohman makes a similar point: Democratic change 'relies on the reflexivity of the democratic order', and this means that not only must citizens

\footnotetext{
2 The systems approach, as I understand it here, is consistent with post-positivism in the sense that it sets expert knowledge within a framework of popular judgment, that is, it locates claims to expertise within a broader interpretive perspective.
} 
in a democracy 'be able to deliberate about matters of common concern', but they must also 'be able to deliberate about the procedures by which they deliberate, the reasons they accept as public reasons, their practices of self-government and so on' (Bohman 2005: 1). A central claim of the deliberative systems approach, then, is that the relations between parts or moments in the deliberative system - the division of deliberative labor - must itself be subject to deliberative justification (Mansbridge et al. 2010). How is this 'meta-deliberation' supposed to take place? How are we to think of the relations between deliberative moments as themselves being subject to deliberation?

One part of the problem is that distributed deliberation requires those 'outside the room,' so to speak, to exercise judgment with regard to deliberations 'inside the room,' whose content and experience they do not share. How can those 'outside the room' have grounds to trust the outcome of deliberations at which they were not present? This difficulty is especially acute where expert deliberations are concerned. To consider this problem, we can distinguish between 'internal' and 'external' legitimacy. ${ }^{3}$ Internal legitimacy derives from the acceptance by the participants of the outcome of a deliberation within a particular institution or body, who 'could see that all views were fully and civilly considered, and that their groups and in the plenary sessions they had opportunities to shape and influence the course of the deliberation, even if they perhaps did not agree with its outcome' (Bohman 2005: 10; see also Ferejohn 2008: 209). External legitimacy, on the other hand, derives from acceptance by institutions or publics outside of the deliberative forum. The idea is that there can be good reasons to accept the outcomes of a deliberation at which one was not present, and these reasons may be different to the ones that establish internal legitimacy for those in the room. The distinction between internal and external legitimacy emphasises (i) the separation

\footnotetext{
${ }^{3}$ This is legitimacy in a local and situated sense rather than at the level of the political system as a whole, though it nonetheless involves some deliberative norms.
} 
between those who are in the room and those who are not, and (ii) that the reasons shared by those in the room will not be necessarily be the same as the reasons that convince those not in the room to accept the outcomes of their deliberation. The problem is that those outside the room share neither the substantive matter of the deliberations, nor the experience that the deliberation was fairly conducted and so on. It is for this reason that Ferejohn describes the situation of those outside the room as one of 'trust without reason-giving' (2008: 208).

This problem can be framed in terms of the sharpness of the boundary between internal and external reasons. If the boundary is impermeable, then what is left to those outside the room is only acclamation or rejection. Such a strict division of labour would, as Chambers points out, 'exclude citizens from substantive deliberation about the issues altogether' (2004: 397). This in turn raises three concerns. It could protect elite deliberation from substantive scrutiny and challenge. It could effectively hand democratic ratification over to a fully 'plebiscitory' (and non-deliberative) process (Chambers 2004: 397). And, as Bohman (2005) argues, to restrict public judgment to the approval or rejection of the initiatives of others could preclude public influence over agenda setting. Chambers, usefully, speaks of whether secluded deliberations are 'porous'. 'Ideally what we want,' she suggests, 'is a public sphere not entirely dominated by plebiscitory reason and closed sessions not entirely dominated by private reason' (Chambers 2004: 398). The 'porousness' of secluded deliberations is particularly important when considering expertise. The problem here concerns the extent to which substantive deliberation can be undertaken by those outside the room as well as those in the room. Another way to put this issue is the extent to which 'internal' or substantive judgments are required or involved in the trust judgment. This gives important democratic shape to the extensive discussions in sociology of science and social epistemology of the capacity of lay people to exercise judgments with respect to expert claims. 
There are two senses in which contestation is crucial to maintaining the division of deliberative labour associated with expertise. One is that secluded deliberation requires a degree of active scrutiny, interaction, and even contestation in order to prevent such seclusion from amounting to the insulation of expert deliberation from substantive scrutiny and challenge. The idea that deliberation is to unfold under the 'force of the better argument' means principally the exclusion of influence deriving from inequalities in wealth and power. However, as Knight and Johnson rightly observe, deliberative equality does not involve equal participation or equal distribution of decision power in the form of votes. Rather, 'the procedures that govern the deliberative phase of democratic decisionmaking protect equality by ensuring that all claims and counter-claims are subject to critical public scrutiny and that, when challenged, any participant must defend her proposal or back her objection with reasons' (Knight and Johnson 1997: 288). Deliberative equality requires not equal participation, but a context of active public scrutiny. Part of the value of such scrutiny and contestation is that it has the potential to influence the behaviour of those who are being scrutinized. What is at stake is not merely the communication of reasons and justifications, such that the norm of public deliberation is honoured merely by the fact that reasons are given by officials for public actions and approved by those subject to their effects, but the influence of the democratic public on expert deliberation.

Another crucial reason for emphasising active challenge has to do with tacit consent. A key feature of tacit consent is that consent only becomes evident by the conspicuous absence of objection over time, and it can only be assumed where there is the live possibility of refusing it. Only where there is the realistic possibility of protesting or refusing to go along with policies and processes can we assume consent from the fact that a policy or process is largely uncontested. Though he does not frame his argument in terms of tacit consent, Warren (1996) makes the possibility of challenge from a 'critical public sphere' central to the generation of authority in a deliberative democracy. His key 
point, which applies also to expertise, is that authority relations are warranted to the extent that they could be publicly scrutinized and challenged, and that the authorities thus have to give justifications in terms of the goods served by such authority. And this in turn requires that such relations, from time to time, actually are brought into question. In the case of a recent vaccine controversy in the UK (see Moore and Stilgoe 2010), although the challenge of vaccine-critical activists brought no substantive policy change, it did raise questions about existing practices, and it did bring to light justifications for those practices in terms of the basic goods the authorities in question were supposed to serve. The point here is twofold. First, the effect of such challenges is not simply to 'erode' authority, but rather to bring to the surface the basic justifications of such practices and present them to a wider public audience. If such practices are indeed successfully justified, then we could be said to have moved from a technocratic to a critical mode of expert authority. Second, by demonstrating the possibility of such challenge and successfully meeting it (if they successfully meet it), the assumption of public consent to those policies and practices that are not contested acquires plausibility. The demonstration of the live possibility of scrutiny and contestation serves to actualize tacit consent. While the regulative ideal of the absence of coercion is highly demanding and often points to the need for secluded deliberation, the presence of criticism at least gives some grounds for the assumption that when authority relations and divisions of labour are not questioned, the absence of criticism indicates tacit consent rather than latent or suppressed dissent.

\section{Deliberation Among Experts}

Expert deliberation differs from the broader public deliberation that has been the principal concern of many deliberative theorists in that it typically does not address moral norms or the common good in any direct way, but rather aims at more narrowly technical judgments. ${ }^{4}$ It is governed not by a

\footnotetext{
${ }^{4}$ This observation does not apply to ethics councils, which are a kind of expert deliberative forum which aims specifically at ideas of justice and the common good (see Moore 2010).
} 
principle of maximal inclusion, but rather selection of participants according to their competence.

However, expert deliberation epitomizes the priority of the quality of argument that is insisted upon by many deliberative democrats. For this reason small group deliberation among specialists has been treated as exemplary by some political theorists. Chambers, for instance, emphasises the high deliberative quality that can be achieved 'behind closed doors' (2004). Rawls describes the Supreme Court as the archetype of public deliberation. And Philippe Urfalino (2006; 2012) describes 'Areopagos'5 deliberations, that is, institutions of committees of the wise, as approximinating the conditions in which the force of the better argument and the epistemic quality of deliberation and decision is given the highest priority. I do not regard such expert deliberations as either the archetype or the most important site of deliberation in a democracy. But I think that in making sense of the place of expertise in a democratic system we must attend closely to expert deliberation. In my discussion in this section I will examine what goes on behind closed doors, and in particular the relation between deliberation and decision, and I will address the problem of how those outside the room can critically relate to a deliberation whose substance they cannot easily access and whose experience they did not share.

Why would citizens lend authority to the views of a group of experts? There are many reasons, but perhaps the most common, and the one I will consider in the rest of this section, is that their deliberations have concluded with consensus. In discussions of the relation between expert knowledge and public deliberation, expert consensus is often thought of as a precondition for informed public deliberation (see Christiano 2012: 52). Yet while it is common to talk of expert consensus, there are two quite different sorts of consensus that can result from expert deliberation. The first is consensus in the sense of uniformity of belief and evaluation. This is what Turner (2003) calls a 'scientific consensus,' and it involves a judgment about the status of a putative scientific fact

\footnotetext{
${ }^{5}$ The Aeropagos was the court of appeal for civil and criminal cases in ancient Athens.
} 
that is not time-constrained or tailored to the demands of a particular situation. Consensus represents the point at which debate within a scientific community comes naturally to rest. This sort of consensus cannot be forced; it is rather the by-product of deliberators arguing over claims and evidence with no time limit and no external demand to close the debate (Rescher 1993: 17). ${ }^{6}$ This image of consensus has had considerable influence on theories of democratic deliberation, in which the ideal of political deliberation has sometimes been framed in terms of a community of impartial inquirers commonly seeking solutions to the various moral and practical problems of living together.

The second is consensus as mode of collective decision across difference. This sort of consensus can be described as decision by 'apparent consensus' (Urfalino 2006) or 'decision by interpretation' (Steiner and Dorff 1980), in which the decision is signalled by the absence of opposition to a proposed consensus statement. Consensus as a mode of collective decision turns on the willing suspension of disagreement, but - in contrast to consensus as uniformity of belief - it does not necessarily involve the disappearance of disagreement. Expert committees and commissions often involve this sort of expert decision, and it also characterises some of the collective statements issued by bodies such as the Intergovernmental Panel on Climate Change. Yet despite its ubiquity, this sense of expert consensus has been far less well explored.

Beatty and Moore frame such active consensus among experts in terms of 'deliberative acceptance,' a model of expert deliberation that highlights the normative potentials of a form of agreement that combines unity with disagreement, unity at the procedural level and disagreement at the level of substance. Deliberative acceptance is an adaptation of Margaret Gilbert's (1987) notion of 'joint

\footnotetext{
${ }^{6}$ On the idea of consensus as essentially a by-product see also Fuerstein (2014).
} 
acceptance,' designed to make explicit the deliberative potentials of this form of collective decision. They propose that

'[a] group deliberatively accepts $\mathrm{p}$ if and only if the individual members, based on the quality of their deliberation, have openly agreed to let $\mathrm{p}$ stand as the position of the group.' Deliberative acceptance involves the willing suspension of disagreement based on the quality of their deliberation. Deliberative acceptance emphasises the demand that the absence of opposition follows a free and full discussion in which the participants themselves agreed that their views were given a fair hearing. One crucial condition for deliberative acceptance is that all participants have an equal opportunity to influence the outcome of the process. This does not mean granting equal weight to opinions in the way that we grant equal weight to votes ahead of the process of tallying them. The weight that attaches to arguments must itself be determined within the deliberative process (problematic as this may be). Equality here means participants have an equal opportunity to persuade one another relying only on the 'force of the better argument'. As Knight and Johnson (1997: 288) rightly observe, the opportunity of equality of influence in deliberative processes does not involve giving equal weight to all opinions, but rather seeks to exclude the influence of inequalities that are arbitrary from the point of view of making arguments oriented to the common good. Deliberative acceptance, then, ideally involves people having an equal opportunity to influence the deliberative process, but if they have pressed their argument yet failed to convince their peers of its value, they may feel compelled to stop opposing a consensus proposal.

Deliberative acceptance also requires that diverse arguments were fully developed and contested. The quality of deliberation has in large part to do with the development and vigorous confrontation of diverse arguments. Without the multiplication, clarification, and contestation of argumentative positions participants may go along with a position without fully considering alternatives and without sufficiently exploring the grounds for the position. Deliberative acceptance aims not for full 
uniformity of belief, but rather at developing disagreement to an extent that those who find themselves in the minority are willing to concede that their arguments were given a fair hearing even if they did not prove persuasive (Beatty and Moore 2010: 209). Deliberative acceptance is in this respect different from Bohman and Richardson's notion of 'deep compromise' - in which agents disagree but their mutual concern and respect leads 'one or both [to] adjust[] his or her ends or goals on the basis of that concern or respect' (Bohman and Richardson 2009: 271; see also Richardson 2002: 147), for deliberative acceptance does not require that agents actually adjust their ends or goals. Deliberative acceptance is also importantly different from Sunstein's 'incompletely theorized agreement,' which involves participants 'accept[ing] an outcome ... without understanding or converging on an ultimate ground for that acceptance' (Sunstein 1999: 125). Rather than avoiding or remaining silent on areas of disagreement, deliberative acceptance requires their thorough exploration.

The development of diverse arguments in a context of deliberative equality is consistent with joint acceptance behind closed doors. In order to give confidence to those outside, however, it is necessary to show that strong alternatives were considered, that the minority was heard, and that they all agreed to let that position stand. It is for this reason that 'deliberative acceptance... involve[s] a vote, which is appropriate for deliberators who count each other as equals' (Beatty and Moore 2010: 210). The vote contributes to the transparency of the proceedings, as well as showing that the position was favoured by a majority of deliberative equals (Beatty and Moore 2010: 210). '[T]here is more to deliberative acceptance than a vote,' they write, '[b]ut, in this case, the count of votes matters' (Beatty and Moore 2010: 210). Does deliberative acceptance simply collapse into majority rule? Is a decision by deliberative acceptance just a decision by majority rule in disguise? I think not, for there are two important theoretical differences. Firstly, under majority rule each person's opinion is at the very outset granted equal weight in the final decision, whereas in 
deliberative acceptance the strength of each person's view is indexed on its persuasiveness to others during the course of the deliberation. In contexts such as an expert committee, as Urfalino emphasises, a participant cannot assert her opinion as one will of equal weight to the others - it is her 'good reason to choose X', and not her 'preference' for it, that has value (Urfalino 2006: 19). Secondly, majority rule presumes a prior unanimous agreement to be bound by the outcome of a vote, whereas in deliberative acceptance, 'even the minority agreed to let the position in question stand as the group's' (Beatty and Moore 2010: 209). This concession is achieved in situ, in a context where the minority had the live possibility of refusing it. 'What is conceded to the minority is acknowledgement of their persistent concerns, as deliberative equals. But deliberative agreement still extracts from the minority a significant concession, the acknowledgement that they were heard, but had not proven persuasive' (Beatty and Moore 2010: 209). Thus, for deliberative acceptance you have to not only secure a majority, but also secure from the minority an agreement that their concerns were heard where they had the live possibility of preventing agreement altogether.

From the point of view of those outside the room, an expert agreement worth deferring to would be one in which (i) there was a minority that forcefully argued its case, and (ii) the minority willingly suspended its dissent and signed on to a group position in virtue of the quality of the deliberation. That is, we would want to see an agreement among experts in which it is evident that a minority went along with the group judgment because of the 'exhaustion of acceptable objections.' This sort of agreement should give people more confidence in the collective judgment of the experts; it would signal and partially reveal the 'internal' quality of deliberation.

\section{The Value of Public Scrutiny}

It is certainly important that experts present the results of their 'internal' deliberations as decisions, that is, that they do not give the impression that nature is speaking through them. Yet it is not 
enough that expert deliberations signal in their conclusions that a process of decision was taking place. There also needs to be a context of active public scrutiny and contestation. Societal practices of contestation and critique are conditions of possibility of the exercise of citizen judgment with regard to complex, expert-mediated issues, and are thus in fact vital to the generation of the democratic authority of expertise. In general terms, social movements and protest groups play a key role in generating the 'context of public criticism' that Warren finds crucial to warranted trust in authority (1996: 56). A number of critical science studies scholars have highlighted the epistemically generative role of 'lay' citizens, who lack formal accreditation but possess experiential knowledge in particular contexts (see Fischer 2000; Wynne 1989). I emphasise here a related role, viewing it not as an alternative expertise but as part of a dynamic process of critical scrutiny of expert authority. There are at least three ways in which such practices of contestation contribute to the conditions of possibility of public judgment of expert claims and practices: the articulation of new issues and identities; oversight and scrutiny of expert practices; and the exercise of powers of prevention.

One important effect of societal practices of contestation and critique is the articulation of issues. Social studies of science have identified in the realm of science and expertise Nancy Fraser's 'subaltern counter-publics', whose value is to 'invent and circulate counter-discourses' and 'formulate oppositional interpretations of their identities, interests and needs' (Fraser 1990: 57). For example, new knowledge suggesting a link between a certain gene and an increased risk of developing breast cancer makes carriers of that gene into concerned parties, without a firm identity as such, nor a clear set of interests, yet with a claim to inclusion as affected parties, and an entitlement to contribute to their self-definition (Callon et al. 2009: 30). Stephen Epstein's study of AIDS activism, for instance, focuses on the 'interventions of lay people in the proclamation and evaluation of scientific claims (1996: 3). Systemically, such activities can contribute to the 
'iteration' of deliberation through the introduction of new actors, arguments, and problem framings into decision processes.

The second contribution is through oversight and scrutiny. The ability of citizens to scrutize elite power is a longstanding democratic concern, and is particularly pressing in the face of the danger of expert domination. As Jasanoff rightly observes, 'growing awareness that policy framings not only solve problems but allocate power ... has led commentators on the politics of science and technology to recommend greater democratic scrutiny of framing processes' (Jasanoff 2005: 194-95). I want to emphasise two important general points about oversight. First, it requires a measure of substantive engagement and deliberative capacity. Second, and related, oversight is active, not passive. It requires the generation of new information and alternative interpretations of existing information. This in turn often calls for the deployment or acquisition of expertise Epstein's AIDS activists put in a great deal of work to be able to interact with experts and articulate their concerns. This is hardly a passive 'watching' in the manner of the parent at the pool keeping half an eye on the kids (Schudson 1999). It requires resource-intensive gathering and processing of information on the part of particular actors. Social movements and 'knowledge associations' (Turner 2003: 77) are often able to take up opportunities to scrutinize the substantive content of expert deliberation in a way that individual citizens are not. Turner (2003: 78) highlights this function of what he calls 'knowledge associations,' and Richardson, in a similar vein, emphasises the importance of 'intermediary advocates' such as the Clean Air Coalition for realizing the 'possibility of contesting or appealing any specially authorized expert determinations' (Richardson 2012: 92).

Empowerment to resist is one further dimension of practices of contestation and critique, which can have the effect of calling forth communicative justifications. The focus on the exercise of powers of 
prevention draws our attention to the power of social movements and knowledge associations to oppose policies through direct action, boycotts, protests and the withdrawal of cooperation. Such refusal and powers of prevention were vividly exemplified in the case of AIDS activists, whose plausible threat of disruption through both protest and non-cooperation in clinical trials was an important condition for their inclusion in the research collective. The threat of exit gave them the opportunity to exercise voice. Such confrontation does not in itself answer any of the substantive questions about what decisions are to be taken in particular cases. The democratic effect comes from forcing putative authorities into communicative justifications of their practices, as Bohman notes in his discussion of this case, including 'even epistemic norms of validity, reliability, and evidence' (Bohman 1999: 590). This point does not rest on any claims that the groups involved are themselves experts in some sense or possess lay knowledge, even though some emblematic cases have involved both. Rather, it makes the limited claim that such practices of contestation and confrontation open up internal expert deliberation to scrutiny and questioning.

\section{Minipublics as a Mode of Scrutiny}

Another mode of enabling and supporting considered judgments in the deliberative system with regard to expertise comes from organized minipublics and other deliberative and participatory democratic innovations. These have been the focus of much attention as aspects of the democratization of expertise (see Fischer 2000; Brown 2009: 251-5; Hamlett 2003). One way to frame their role in a deliberative system is in terms of their ability to support meta-deliberation. This in turn can be analysed in terms of informing the deliberation of wider publics. Yet informing public deliberation here does not mean reproducing among a wider public the level of debate found in the deliberative forum or providing citizens with substantive information on the issue at hand so that they can judge for themselves. Rather, it involves giving good grounds for taking up the judgments of others. 
Why would citizens lend authority to the views of a randomly selected group of their peers? One sort of answer has to do with representativeness (see MacKenzie and Warren 2012: 105-7). As Goodin and Dryzek (2006: 221) put it, the minipublic should represent 'the diversity of social characteristics and plurality of initial points of view in the larger society'. Fishkin speaks of the sample of citizens in his minipublics as a 'mirror' of the broader public. Yet to talk of minipublics 'reflecting' the wider population would be to miss an important wrinkle: they resemble the public minus the partisans. They construct a 'pure' public (Braun and Schultz 2010) using random selection (or stratified random sampling for smaller groups) and excluding 'partisans,' citizens who already have strong commitments on the issue at hand, as well as any citizens with direct financial, familial or professional conflicts of interest. The representativeness of the mini public thus involves not strict resemblance. Nor is it representation in the sense of being authorised, accountable, or responsive to constituents. Rather, the representativeness takes the form of generality, an absence of organised particular interests. One reason for preferring 'pure' publics is that they can promote inclusion of 'interests and perspectives that are unorganized, inarticulate, and latent in proportion to their presence in the larger public' (MacKenzie and Warren 2012: 106). Further, those already engaged in a particular issue have a discursive advantage in any deliberative context, and their inclusion thus introduces a discursive inequality (Kadlec et al. 2007: 10). Nor must it be the case that 'pure' publics are pliable publics. Kleinman et al. (2011) show, for instance, that the exclusion of organised interests does not mean that citizens participants are mere 'blank slates'.

Another broad set of reasons for granting special weight to the judgments of minipublics has to do with the claim that they are 'better informed on the issues and had the opportunity and motivation to examine those issues seriously' (Fishkin 1997: 162). MacKenzie and Warren have described this sort of deference in terms of trust in minipublics as 'information proxies'. By 'information proxy' 
they mean that citizens who did not share the information and argument, or the experience of the deliberation, may nonetheless choose to defer to the judgment of the mini public if they think it was competent and representative of the broader public. The value of the mini public is to provide 'information shortcuts' to an inattentive broader public (MacKenzie and Warren 2012: 103). Yet it would seem that this role for mini publics involves not so much informing public deliberation, as displacing it. The minipublic would do the job of weighing a wide range of information and arguments, balancing conflicting interests and reaching a considered collective judgment. The wider public, on the 'information proxy' account, would treat the collective judgment of the minipublic as a signal about how they ought to vote. Trusting the judgment of the minipublic in this case is an alternative to informing oneself of all the substantive arguments. When MacKenzie and Warren talk of trust in general terms they seem to invoke the idea of blind deference: 'When an individual makes a decision to trust, he is entrusting a good in which he has an interest to another agent - to an individual, a group, or an institution. In deciding to trust, he is also deciding to forgo any direct judgment about the use or protection of a good. All problems of knowing about the good - how to maintain, protect, further, or develop it - are off-loaded onto the trustee' (MacKenzie and Warren 2012: 99; my emphasis). Trust in this sense is consistent with total ignorance on the substance of the matter in question. It also means foregoing any 'monitoring or other forms of active engagement' (MacKenzie and Warren 2012: 99). Monitoring would signal an absence of trust altogether. However, while citizens may be ignorant on the substance of the issue, the 'trust decision' depends principally, they suggest, on judgments about the motivation and the competence of those who would be deferred to. MacKenzie and Warren recognize that the 'shortcut' citizens are looking for is one that tells them about the quality of the deliberation in the room, that is, their decision to defer depends on a judgment as to whether the 'information cues emanating from minipublics might be considered trustworthy because these recommendation have been tried, tested, and accepted by informed participants in a discursive arena' (MacKenzie and Warren 2012: 113). 
This has led Lafont to claim that the 'information proxy' function relies on 'blind deference' (Lafont 2014: 11). This is not entirely fair, since there is clearly an active judgment taking place (at least ideally), and this judgment is related to suppositions about the quality of the deliberation. The confusion, I think, comes from MacKenzie and Warren's framing of the information proxy function in terms of passivity. The ambiguity is that passivity could be taken to apply either to the dimension of participation or to the dimension of judgment. Thus, when they emphasise that citizens make 'active choices to remain passive' (MacKenzie and Warren 2012: 99), they mean that citizens are making an active judgment to remain passive in the dimension of participation. To be passive in the dimension of judgment would indeed be to blindly defer. It is possible, of course, that blind deference could be construed as improving deliberative quality at the system level by enriching the environment in which citizens more or less unreflectively take their informational cues - the deliberative equivalent of adding fluoride to the water supply rather than relying on citizens to remember to brush their own teeth. But this is not what they argue. Rather, they emphasise the value of providing the means for citizens to make active judgments about when and where to direct their critical attention and participatory energies. Thus, when they talk of 'good' passivity, they mean non-participation informed by an active judgment. They are arguing not for blind (or passive) deference, but for active deference to the judgments of a minipublic. The active judgment here does not bear on the substantive arguments and information. It bears rather on second-order or external reasons. Without actually sharing the information, arguments, and experience of deliberation, those outside the room can, nonetheless, have good reasons of a different sort to trust the judgments of those in the room. This is neither a straightforward matter of informing or displacing public judgment, but providing opportunities for citizens to use their judgment to allocate their attention and participation in a more fruitful way. 
The idea of deferring to the judgments of a minipublic involves entrusting to them the job of weighing conflicting interests and making judgments. Yet if we are to trust the political judgment of a group, both the strength of opinion in the group and the quality of argument are crucial considerations. Here we encounter a variant of the problem discussed above in the context of expert deliberation. MacKenzie and Warren (2012) point to the need for 'consensus' in the room, arguing that unanimity or near unanimity among the deliberators is more likely to command deference than a bare majority. A bare majority would signal a clearly divided group. This would alert us to pay closer attention to the substance of the dispute, and make it harder choose a side. However, while unanimity or near unanimity can be a mark of genuine convergence on a common answer, it can also mean that the deliberation was pushed to premature consensus or that the participants had a hidden bias. Does this mean we should look for somewhere between bare majority and unanimity? Lafont, picking up on this point, incredulously asks what degree of consensus should 'trigger trust' (2014: 18). 65 percent? 55? 95? She then rejects the 'quantitative' approach to trust altogether (2014: 17), declaring that the decision whether to 'endorse a specific recommendation... cannot be a matter of degree' (Lafont 2014: 17). Yet it seems to me that instead of asking what degree of agreement within the room would command authority outside the room (55\%? 65\%? 95\%), the key is what outsiders can infer about the quality of deliberation in the room from the character of the agreement. In particular, we should separate the question of the degree of substantive agreement on the issue, and the agreement to endorse the collective outcome based on the quality of the deliberative procedure. In the terms I have been using, the participants may be near unanimous in their acceptance of an outcome which is only positively endorsed by a smaller majority - we thus might frame the combination of strength of opinion and quality of argument in terms of 'deliberative acceptance'. Recall that after the British Columbia Citizens' Assembly had decided on two electoral systems that most closely maximised the values they thought an electoral system should realise, they voted between these two options, with STV winning 123-31. They next voted 
142-11 against recommending retaining the current system. And then finally they voted 146-7 to recommend a version of STV to the citizens of British Columbia in a referendum. We might expect the first and third votes to be the same. Why would someone who favoured MMP over STV then vote to recommend STV to the wider electorate? It seems plausible to say they still believe that MMP would be better than STV. But the latter result addresses precisely the question involved in deliberative acceptance: whether you endorse this as the opinion of the group. This latter vote, we might then say, is an indicator of the participants' assessment of the quality of deliberation, a claim that 'epistemic justice was done', as Beatty and Moore (2010: 209) put it, that their arguments were heard but that they didn't win out. It is this kind of agreement, I think, that best justifies MacKenzie and Warren's intuition about the value of near unanimity as a signal for outsiders who might take up the conclusions of a minipublic.

\section{Deliberative Elitism?}

On one level there is a similarity between the ways in which small group public deliberations and expert deliberations can reach a conclusion. MacKenzie and Warren's account of voting and consensus in the production of a collective judgment at the end of the BC Citizens' Assembly strongly resembles 'deliberative acceptance'. In both cases it remains to be explored how the different ways of concluding deliberation open up or foreclose opportunities for those outside the room to exercise judgment in taking up (or rejecting) the results of those deliberations. Thus, recent research on the relation between deliberative quality and the mode of collective decision has explored the possibilities of various forms of decision-making such as 'apparent consensus' (Urfalino 2006), 'deliberative acceptance' (Beatty and Moore 2010), 'metaconsensus' (Dryzek and Niemeyer 2006), and even 'deliberative voting' (Moore and O’Doherty 2014). This contributes to a small but growing body of work on the ways of reaching 'non-coercive communicative agreement[s]' that involve neither full unanimity nor mere modus vivendi, but 
which conclude with 'a kind of consensus' in the sense of a 'genuine agreement that the outcomes are right or fair' (Mansbridge et al. 2010: 70).

However, at the systemic level, one of the important functions of minipublics is as a means of enacting public scrutiny, yet in a way that does not fall prey to the characteristic biases of contestation by movements in the public sphere. The scrutiny function that can potentially be provided by minipublics, then, is distinct from, and complementary to, the sort of scrutiny embodied in the movements and advocacy groups of the critical public sphere. This raises an important systemic danger, which is that minipublics and other innovations of 'invited' participation could diminish or even displace the more informal processes of social movement contestation and protest (Mansbridge et al 2012: 17). On this basis it has even been argued that minipublics represent 'a peculiar variety of elite rather than deliberative democracy' (Lafont 2014: 9). They imply a form of elite democracy in that citizens are asked to 'blindly defer to the deliberations of a few selected citizens' (Lafont 2014: 9), but it is peculiar because those few selected citizens are neither experts nor a consolidated political elite, but a randomly selected group of ordinary citizens. Both Urbinati (2010: 73-75) and Lafont argue that, while mini publics may not formally substitute for public debate and democratic decision, the logic implicit in the claim that mini publics should be authoritative in public debates points to an alarming endgame in which mini publics would crowd out both deliberation in the public sphere and undercut the collective decisions issuing from electoral-representative institutions. They would thus contract rather than enrich democracy (Urbinati 2010: 74), and 'diminish rather than increase the legitimacy of the deliberative system as a whole (Lafont 2014: 2). The deeper concern, then, is not just that minipublics might in practice be captured by elite interests, but that they are essentially elitist, that the better they work, the more they undermine democracy. 
Lafont's argument involves an all-or-nothing account of citizen deliberation: either they fully own the arguments for themselves (the long march, we might say), or they 'blindly defer' to others (the 'short cut'). Lafont seems to deny the possibility of citizen judgment in deciding whether or not to take up the results of the deliberations of others. She does not consider the possibility of secondorder or external reasons for choosing to rely on the judgments of others in particular contexts. She insists that any 'recommending force' must amount to 'blind deference' - she cannot imagine citizens having good reasons to take up the outcomes of the deliberations of others that are not the same as the reasons shared in the room. This is particularly odd in view of a comment she makes in passing to the effect that she thinks citizens could have such reasons to defer to real expert deliberations. Lafont appears to accept that a perfectly good option for passive citizens would be to rely 'on the recommendations of groups whose political views they share or on experts whose judgments they trust. However imperfect, this type of deference is still less blind than deference to the majority of a randomly selected group of citizens' (Lafont 2014: 18). Elsewhere she asks, 'why should their judgments have any more recommending force than those of other experts that may be substantively superior on their merits?' (Lafont 2014: 11; my italic). The problem with mini publics, it seems, is that they are too informed to descriptively represent a broader public, but not quite well-informed enough to be worthy of the deference owed to real experts. She mentions the comparison to expert deliberation only in passing, and does not explain why choosing to rely on a minipublic you believe to be representative and competent would be any more 'blind' than relying on experts you believe to be competent and without conflicts of interest.

Both Lafont and Urbinati argue that at the systemic level, minipublics displace rather than supplement the activities of the critical public sphere. Whether this sort of crowding out is evident in practice is an empirical question. Yet the theoretical danger is that it mistakes the democratic potentials of minipublics by treating them as a microcosm of a deliberative democracy that would 
displace, and not simply supplement, contestatory discourse in the public sphere and collective decision in electoral-representative institutions. Because Lafont's criticisms effectively test the value of a deliberative mini public against the standards of a complete theory of democratic legitimacy, they miss the more limited potentials of minipublics as supplementary institutions that have the potential to enhance in particular and limited ways the conditions for the formation of collective judgments in the public sphere and the alignment of policy with legitimately constructed democratic decisions. Rather than viewing minipublics as the thin end of a wedge that threatens to weaken both civil society contestation and electoral-representative legitimacy, we might frame them as having democratic potentials as a way of informing wider citizen deliberation and scrutinizing, monitoring and judging expert government. That they do so in a context of social movements and critical associations (which will orient more confrontationally) is important; but that they have functions that are distinct from those of confrontation is also important. These potentials fall well short of participatory ideals, but they need not simply amount to a new form of elitism.

\section{Conclusion}

In this essay I have framed the systemic role of expertise in democracy in terms of a dynamic tension between the need for expert deliberations to remain both distinct from and responsive to wider public concerns. This means on the one hand that deliberations among experts need to be conducted in ways that remain porous or open to the possibility of judgment by those outside the room. I suggested that 'deliberative acceptance' is one useful way of conceptualizing the need both for consensus among experts and for ways of signalling that such consensus amounts to a decision, a collective judgment of experts, which is to be deferred to, if at all, on the basis of judgments of the deliberative conditions under which it was reached. On the other hand, public judgment requires that there is an active context of scrutiny and critique. This is produced by the social movements and activists who populate the critical public sphere, and who direct critical attention to the claims 
made by experts and the conditions under which they produced them (critics of the climate science consensus produced by the IPCC, for instance, would fall under this heading). Yet minipublics may find a place as a complementary mode of scrutiny of expert practices. Thus, the integration of expert authority in a democratic systems must take into account not only expert deliberative moments themselves, but also the wider context of scrutiny and contestation in civil society, and the potential for minipublics in mediating and moderating this scrutiny function. 


\section{References}

Beatty, J., 2006. 'Masking Disagreement among Experts.' Episteme: A Journal of Social Epistemology, 3(1-2), 52-67.

Beatty, J. and Moore, A., 2010. 'Should we Aim for Consensus?' Episteme: A Journal of Social Epistemology, 7(3), 198-214.

Bohman, J., 1999. Democracy as Inquiry, Inquiry as Democratic: Pragmatism, Social Science, and the Cognitive Division of Labor. American Journal of Political Science, 43(2), 590-607.

Bohman, J., 2005. 'Legitimate Institutions for Democratic Renewal: Constitutional, Democratic, and Deliberative.' Paper presented to the Citizen-Designed Democratic Processes Workshop, Peter Wall Institute, University of British Columbia. June 10-11.

Bohman, J., and H. S. Richardson, 2009. 'Liberalism, Deliberative Democracy, and "Reasons that All Can Accept."' Journal of Political Philosophy 17(3), 253-274.

Braun, K. and S. Schultz., 2010. ““... a certain amount of engineering involved”: Constructing the public in participatory governance arrangements.' Public Understanding of Science 19(4): 403-19.

Brown, M., 2009. Science in Democracy: Expertise, Institutions and Representation. Cambridge, MA: MIT Press.

Callon, M., P. Lascoumes, and Y. Barthe, 2009. Acting in An Uncertain World: An Essay on Technical Democracy. Cambridge, MA: MIT Press.

Chambers, S., 2004. Behind Closed Doors: Publicity, Secrecy and the Quality of Deliberation. The Journal of Political Philosophy, 12(4), 389-410.

Christiano, T., 2012. Rational Deliberation Among Experts and Citizens. In Deliberative Systems: Deliberation at the Large Scale. Edited by John Parkinson and Jane Mansbridge. Cambridge: Cambridge University Press, 2012, 27-51.

Dryzek, J. S., and S. Niemeyer, 2006. Reconciling Pluralism and Consensus as Political Ideals. American Journal of Political Science 50(3), 634-649. 
Epstein, S., 1996. Impure Science: AIDS, Activism and the Politics of Knowledge. Berkeley and Los Angeles, CA: University of California Press.

Ferejohn, J., 2008. Conclusion: The Citizens' Assembly Model. In Designing Deliberative Democracy: The British Columbia Citizen's Assembly. Edited by Hilary Pearse and Mark E. Warren. Cambridge: Cambridge University Press, 192-213.

Fischer, F., 2000. Citizens, Experts and the Environment: The Politics of Local Knowledge, Durham and London: Duke University Press.

Fishkin, J., and R. Luskin, 2005. 'Experimenting with a Democratic Ideal: Deliberative Polling and Public Opinion.' Acta Politica, 40(3): 284-298.

Fishkin, J., 1997 [1995]. The Voice of the People. Public Opinion and Democracy. New Haven and London: Yale University Press.

Fraser, N., 1990. 'Rethinking the Public Sphere: A Contribution to the Critique of Actually Existing Democracy.' Social Text 25/26.

Fuerstein, M., 2014. 'Democratic Consensus as an Essential By-product.' Journal of Political Philosophy, 22(3): 282-301.

Fung, A., 2003. 'Recipes for Public Spheres: Eight Institutional Choices and Their Consequences.' Journal of Political Philosophy, 11: 338-67.

Gilbert, M., 1987. 'Modelling Collective Belief'. Synthese 73(1): 185-204.

Goodin, R. E. and J. S. Dryzek., 2006. 'Deliberative Impacts: The Macro-Political Uptake of MiniPublics.' Politics \& Society 34(2): 219-244.

Goodin, R. E., 2005. ‘Sequencing Deliberative Moments.’ Acta Politica 40: 182-196.

Goodin, R. E., 2008. Innovating Democracy. Oxford: Oxford University Press.

Gutmann, A., and D. Thompson, 2004. Why Deliberative Democracy? Princeton and Oxford: Princeton University Press. 
Hamlett, P., 2003. “Technology Theory and Deliberative Democracy.” Science, Technology \& Human Values 28(1): 112-140.

Jasanoff, S., 2005. Designs on nature: Science and democracy in Europe and the United States. Princeton: Princeton University Press.

Kadlec, A. and W. Friedman, 2007. Deliberative Democracy and the Problem of Power. Journal of Public Deliberation, 3(2), Article 8: 1-26.

Kleinman, D., J. Delborne, and A. Anderson., 2011. 'Engaging citizens: The high cost of citizen participation in high technology.' Public Understanding of Science 20(2): 221-240.

Knight, J., and J. Johnson, 1997. What Sort of Equality Does Deliberative Democracy Require? In Deliberative Democracy: Essays on Reason and Politics. Edited by J. Bohman and W. Rehg. Cambridge, MA: The MIT Press, 279-320.

Lafont, C., 2014. 'Deliberation, Participation, and Democratic Legitimacy: Should Deliberative Mini-publics Shape Public Policy?' Journal of Political Philosophy. Article first published online: 22 Jan 2014. DOI: 10.1111/jopp.12031

Mackenzie, M. M., and M. E. Warren, 2012. Two Trust-based Uses of Minipublics in Democratic Systems. In Deliberative Systems: Deliberative Democracy at the Large Scale. Edited by J. Parkinson and J. Mansbridge. Cambridge: Cambridge University Press, 95-124.

Mansbridge, J., J. Bohman, S. Chambers, D. Estlund, A. Follesdal, A. Fung, C. Lafont, B. Manin, and J. L. Marti. 2010. The Place of Self- Interest and the Role of Power in Deliberative Democracy. Journal of Political Philosophy 18(1), 64-100.

Mansbridge, J., J. Bohman, S. Chambers, T. Christiano, A. Fung, J. Parkinson, D. Thompson, M. Warren., 2012. 'A Systemic Approach to Deliberative Democracy.' In Deliberative Systems: Deliberative Democracy at the Large Scale. Edited by J. Parkinson and J. Mansbridge. Cambridge: Cambridge University Press, pp. 1-26.

Mansbridge, J., 1999. "Everyday Talk in the Deliberative System.” In Deliberative Politics, ed. Stephen Macedo. New York and London: Oxford University Press, p. 211-39. 
Moore, A., \& Stilgoe, J., 2009. 'Experts and anecdotes the role of “anecdotal evidence” in public scientific controversies.' Science, Technology \& Human Values, 34(5), 654-677.

Moore, A., 2010. Public bioethics and deliberative democracy. Political Studies, 58(4), pp.715-730.

Moore, A., \& O'Doherty, K. (2014). 'Deliberative Voting: Clarifying Consent in a Consensus Process.' Journal of Political Philosophy, 22(3): 302-319.

Moore, A. (2014). 'Deference in Numbers: Consensus, Dissent and Judgement in Mill's Account of Authority.' Political Studies, 62(S1), 187-201.

Nullmeier, F., and T. Pritzlaff, 2010. 'The implicit normativity of political practices. Analyzing the dynamics and power relations of committee decision- making.' Critical Policy Studies 3(3-4): 357-374.

Parkinson, J., 2006. Deliberating in the Real World. Oxford: Oxford University Press.

Parkinson, J., 2012. Democratizing Deliberative Systems. In J. Parkinson and J. Mansbridge (eds.), Deliberative Systems: Deliberative Democracy at the Large Scale. Cambridge: Cambridge University Press, 151-172.

Rescher, N., 1993. Pluralism: Against the Demand for Consensus. Oxford: Oxford University Press.

Richardson, H., 2002. Democratic Autonomy: Public Reasoning about the Ends of Policy. Oxford: Oxford University Press.

Richardson, H., 2012. 'Relying on Experts As We Reason Together.' Kennedy Institute of Ethics Journal 22(2): 91-110.

Schudson, M., 1999. The Good Citizen: A History of Civic Life. Cambridge, MA: Harvard University Press.

Steiner, J. and R. H. Dorff, 1980. Decision by Interpretation: A New Concept for an Often Overlooked Decision Mode. British Journal of Political Science 10(1), 1-13. 
Steiner, J., Bächtiger, A., Spörndli, M., \& Steenbergen, M., 2004. Deliberative politics in action: Analysing parliamentary discourse. Cambridge: Cambridge University Press.

Sunstein, Cass R. 1999. Agreement without Theory. In Deliberative Politics: Essays on Democracy and Disagreement, ed. Stephen Macedo. Oxford: Oxford University Press, 123-150.

Thompson, D. F., 1999. 'Democratic Secrecy.' Political Science Quarterly 114(2): 181-193.

Thompson, D. F., 2008. 'Deliberative Democratic Theory and Empirical Political Science.' Annual Review of Political Science 11: 497-520.

Turner, S.P., 2003. Liberal Democracy 3.0. London, Thousand Oaks, New Delhi: SAGE.

Urbinati, N., 2010. Unpolitical Democracy. Political Theory 38(1): 65-92.

Urfalino, P., 2006. Apparent Consensus and Voting: Two Modes of Collective Decision- Making. Presented at the workshop on The Mechanisms of Collective Decision-Making. Adriano Olivetti Foundation, Rome, April 29.

Urfalino, P., 2012. Reasons and Preferences in Medicine Evaluation Committees. In Landemore and Elster (eds.), Collective Wisdom: Principles and Mechanisms. Cambridge: Cambridge University Press, 173-202.

Warren, M. E., 1996. 'Deliberative Democracy and Authority.' The American Political Science Review 90(1): 46-60.

Warren, M. E., and H. Pearse, 2008. "Introduction: democratic renewal and deliberative democracy.” In Designing Deliberative Democracy: The British Columbia Citizen's Assembly, eds. Mark E. Warren and Hilary Pearse. Cambridge: Cambridge University Press, p. 1-19.

Wynne, B. (1989) 'Sheepfarming after Chernobyl: A case study in communicating scientific information.' Environment: Science and Policy for Sustainable Development, 31(2): 10-39. 